\title{
The Implementation of Sexuality Education Program for Early Childhood in Stimulating Psychososial Development in Pearl Playschool
}

\author{
Siti Sarah Hajar Nurfuadah \\ Early Childhood Education Program of Graduate School of Universitas Pendidikan Indonesia, Indonesia \\ Corresponding e-mail : c c_tamadhar_az@student.upi.edu
}

\begin{abstract}
Recently, the issue of prosperity, healthy and protection to young children that are vulnurable to sexual abuse,exploitation and violence has been developing quite significantly. This has raised a question " To what extent has the early childhood education helped to give knowledge and understanding about sexuality as an effort to enable the children to recognize themselves, to be protected from violence, sexual abuse and exploitation? What kind of program that can be applied or tried? and how to involve parents so that the program can run effectively and succesfully?As a teacher, the author is urged to share one of the sexuality education program in early childhood in Pearl Playschool specifically aged 5-7 years old which consists of program for school and program for parents in Narrative Analysis. The topic about "Auratku/My Personal Parts" has been running for about 2 years in "I Love Muhammad Program" as a form of care from the school to the recent child development as well as a real effort to prepare a better and tougher generation in the future. The implication of this paper, the author as one of the teachers in Pearl Playschool would like to describe her own experiences in making the program and doing the stimulation or applying the practice of sexuality education in early childhood. The writer would also like to state that after the program run, there were changes in the knowledge, understanding and behavior of children that are related to their psychososial development.
\end{abstract}

Keywords : Sexuality Education, Early Childhood, Psychososial, Parents Role

\section{INTRODUCTION}

There are some people who delay or avoid talking or discussing when it comes to the topic of sexuality, especially when the audience is children. This is reasonable because this topic is still considered a taboo and it tends to be impolite to talk about it in public or many people in our culture.

This is due to the thought that sex is like porn and is very private so that it cannot be discussed to other people. The definition of it is still narrow. The talk about sexuality is only meant to be sexual intercourse especially when it is related to kids. (Dwiyani, 2004).
In Sugiasih's survey about the needs of parents in getting involved in sexuality education in Posyandu Nirwayana Bandung in 2006, it was shown that the average score was $91,29 \%$. It means that parents have positive response and feel the needs of giving sexuality education to children. However, half of the parents chose to delay to do that until their kids are older enough or let them know from their friends later.

This occurs because of the shame feeling and the unreadiness of parents to discuss that matter with their children, especially children in early years (Sugiasih, 2006). This was also stated by Turnbull (2012) that many parents still feel ashamed and 
uncomfortable to talk with their kids about things related to sexuality.

Nowadays, it is really alarming to see the massive and widely spread sexual abuse and assault to children of early years. It shows that it is necessary to know our effort in giving the knowledge, understanding and skills to the kids about this. Has the effort done optimally? Do the children know and understand their conditions i.e their body and feeling and how to react to their body and feeling when they interact with their environment?, or how the children can spontaneously avoid and save themselves from the sexual violence of the people around them? Be it adults or other kids? strangers or their relatives? How-to prevent the kids from inappropriate acts that are contrary to the norms? How to prevent them from becoming the actor of the sexual violence themselves? Furthermore, how can the children protect themselves while the parents or the adults around the children are ashamed and not ready to share the knowledge and understanding in the sexuality education?

The importance of early years' sexual education is much related to the most important education elements i.e home and school. Home is surely related to the parenting pattern and parents-kid's relationship in sexual education.

Additionally, school is equally important element in making a program of sexuality education to early years' children. In fact, it is the right place.

Based on WHO Regional Office for Europe and BZgA Standards for Sexuality Education in Europe, several sexuality education practitioners agreed that this kind of education should be given as early as possible with the developing above-mentioned issues (WHO, BzGA. 2010).

In order to develop knowledge, understanding and skills of children in this sexuality education, Pearl Playschool, having the Islamic vision, developed a program called "I Love Muhammad", a specially made program to introduce Prophet Muhammad deeply to be the role model of children in how to behave such as how to take care of themselves and protect themselves.

In this program, there are several activities focusing on how the children know themselves for example knowing their parts of body, their functions, their genders, roles and feelings. Other activities are knowing their own feelings, protecting themselves from the people who intend to do inappropriate things to their body. This program also involved parents in the process. After this program, had run for about 2 years, the children more understood about the content of the sexual education and their skills helped them in terms of their psychosocial both in school (based on observation) and at home (based on their parents talks).

Introducing sexual education needs time and gradual process based on ages and the development stages. Children can be introduced to simple things around them such as knowing their body anatomy as stated by Chomaria (2014) that sexuality education is begun by introducing their parts of body. After the children know their parts of body, they are taught of how to clean their parts of body including their genitals. Ideo (2014) stated that introducing toilet training to children by asking them to clean their own genitals while they are 2 years old, if they are already able to do so.

This can help children to not to depend on other people as well as protect their bodies from other people's touching.

A case study of sexuality education implementation in early years has been conducted by Nurhasanah (2015) in one of schools in Bandung. The result shows that the sexuality education implementation in early years is focused in three parts i.e related to introducing types of sex, keeping the cleanliness of body arts and avoiding sexual abuse in early years as well as normative education. Sexuality education is applied continuously and constantly by cooperation between the school and the parents, supported by the facilities needed in it.

Based on the findings, the author is interested to share what she did, felt and created from the program in the view point of a teacher running the program.

\section{METHODOLOGY}

The method used in this research is qualitative method. The method is used to learn about the objective condition of a new program. This is in line with Creswell (2010) who stated that qualitative research is as a method to understand social or human problems based on holistic picture creation using words, to report the informant's point of view in details and is arranged in a scientific background.

The qualitative research done by narrative research. By this method, the author tried to understand the identity and world view of a person based on narration that she heard or said in her daily activities.

In this Narrative research, the author reflected to be able to deliver all stories under the topic of "Auratku" based on the period of that used topic because the data analysis that is used is personal 
account. This is in line with the statement of Plumer (1983) and Creswell (2015).

This research took place in an early year's educational institution in Bandung. Pseudonyms used throughout this article for the name of the school as Pearl Playschool. The author selected this subject because the program development was conducted there and the author was one of the teachers in the school as the teller. The narrative study possibly has specific contextual focus, for example the story told by teachers or children in the classroom (Ollerenshaw, J.A., \& Creswell, J.W., 2002)

To help analyzing the data, the author collected all existing data be it in the forms of program, report of implementation, portfolio (photos, video, and products), evaluation of the program, interview with parents and teachers.

\section{RESULT}

Pearl Playschool is one of schools established since 1995. It began as an English club named Young. In the following years, some parents asked the foundation of the club to open Playgroup so that Pearl Playschool was founded, with its vision namely Islamic, Global and Smart. By the passing time and great trust from parents on the programs learning methods, Pearl Playschool has been developing its service continually.

The program "I Love Muhammad" is one of the teaching programs made for 5 years ago, as an effort to maximize the learning that can improve value and character of the kids. The initiative of this program came from the consideration that many facts showed that children do not know and understand basic good and bad deeds strongly.

Pearl Playschool is a school having the vision "Islamic". It means that the children's knowledge and understanding about Prophet Muhammad as a role model in their early years are of important points because Pearl Playschool wants the students to be able to behave and act honorably like Prophet Muhammad PBUH. The effort can be done by creating good daily habits of children both at school and home. Pearl School considered that the introduction of the prophet and his attitude must be taught in early years and continuously until the highest level in the school. This includes the way prophet eat, drink, speak, wear cloth and sleep, his relationship with family, friends and neighbors, his spirit of learning, cleanliness etc. This is done as a manifestation of the law No. 20 of 2003 on National (Indonesian) Education System, Education is a conscious and deliberate effort to create an atmosphere of learning and the learning process so that learners are actively developing the potential for him to have the spiritual power of religion, selfcontrol, personality, intelligence, character, and skills that required by themselves, society, the nation and the state. In this context, the prophet also teaches how to dress, how to keep cleanliness, how to interact with others and protect own selves.

By the running time, the school's needs to introduce good daily habits continuously and to develop the awareness of importance of sexuality education to early years' children regarding the concern of the school to the health, safety and security of the children in relation to the children's awareness of him/herself, their feeling and with their awareness of who can touch or not touch themselves.

Generally, there are at least some reasons and purposes why sexuality education is important to child from an early age (Tretsakis, 1993).

Based on that consideration, Pearl Playschool for two years ago, included the topic of "Auratku/My private parts" in the program that consists of several activities about: parts of my body, its functions, its way of work, its way of maintenance. They also learn about why they are different from one another, why they should wear clothes, know 4 red zones, talk to strangers and learn how to say "No". All of these activities were in the forms of storytelling, role play or simulation so that the children could have the opportunity to practice them at other times and when needed, not only remaining a knowledge. This is in line with the statement saying that "Sexual Education is how to direct and give healthy understanding of sex in terms of physical, psychological, and spiritual health" (Roqib, 2008).

Some habits and activities are more paid attention to such as: the boys and girls wear their clothes separately. For the girls wearing short skirt they are suggested to wear additional legging or long pants inside.

Besides the sexuality education at school, to maximize the effort to protect the health, safety and security of the children, parents' involvement is really important as it said that ssupport from parents emotionally and physically is able to facilitate and prepare their children in later life when they are adults (Novilla, et all, 2006).

The topic of "Auratku" was given gradually in turns with other topics related to child's daily activities. Usually, the topic of "Auratku" was still integrated to other topics as a review or reinforcement. Each topic was given once a week. 
The method used was storytelling using big books, drama playing from the movie, role play and simulation.

For this program, the school provided special teacher but for several things such as socialization and implementation of it, all teachers were involved.

Additionally, the school conducted several programs for the parents i.e parenting events specially made to discuss sexuality education for early years' children and the sharing of articles or topics related to it such as: Early years' Islamic sexuality education, gaining confidence to talk about sexuality to children, how my kids dress, knowing the differences and the similarities between girls and boys, and other topics related to sexuality education for early childhood.

After collecting the data in the school, the author did interview to several teachers and parents.

The result of interview with teachers shows that there is change of the children in terms of their daily habits. They are as follows: the children are more attentive and careful when they want to put on or put off their clothes after they go to toilet/restroom, they seem to be more comfortable with more closed costumes such as legging inside the skirts or long pants, they remind the other friends if there are something that make them feel uncomfortable related to their bodies, they understand more about the roles of boys and girls when interacting, etc.

Meanwhile, the difficulty faced by the teachers was when there were a lot of questions from the children about the given topics. They were not ready to answer the questions given by the children because of the limited knowledge they have about related topics.

The interview with several parents shows some findings such as the questions about the strategies to conduct sexuality education to their own kids such as: for 2 years old the beds are separated, not to sleep in one blanket, hiding when they want to wear clothes, getting used to be ashamed if the children get naked in front of other people, giving and letting them wear appropriate clothes matched with the sex, not talking to strangers.

Meanwhile, the difficulties that the parents faced were as follows: consistency, answering children's questions about sexuality, reminding the children not to be naked even if they are at home, reminding people around them who suddenly kiss the children without any permission, controlling the children who watch unintentionally the inappropriate scene or picture when playing games, watching TV or browsing on the internet.
Additionally, the result of the program as told by parents was as follows: the girls get used to ask to wear legging inside their skirts, some students start to ask to sleep alone, the kids remind their family members to close their body, the kids were courageous to refuse or say "no" when there are some people who touch their parts of body especially the four zones (mouth,breast,genitals and bottom), the children told their parents story if there were some uncomfortable feelings. The children reminded their friends about the materials of sexuality education they got. For example: "your underwear is visible, please cover it! It is a shame. "Don't touch my bottom!". Why don't you wear pants, wear it, please! "Mom, I want to take a bath alone, close the door, please!" etc.

Based on the above research, there is a match between the things delivered by Erickson in psychosocial development theory i.e sexuality education in early childhood in Pearl has developed children's ability to solve their basic conflicts developing in early years that is Autonomy vs Shame \&Doubt, signed by the activity of toilet training in school and home, Initiative vs Guilt marked by their body exploration, their curiosity about the functions and how to protect them so that they wouldn't feel guilty about what happened to themselves because we did not give them the chance to get to know themselves and their feelings (Santrock, 2007).

\section{CONCLUSION}

Sexuality education in early childhood applied in Pearl Playschool through interesting and continuous topics and presented using storytelling, role play, simulation, etc. that are suitable with the vision, mission and school's values in the children daily activities both at school and at home, especially in how they get used to take care of themselves by taking a bath alone, wear their own appropriate clothes that can protect themselves, remind their friends, parents, families or other people about what is comfortable and uncomfortable for themselves. The relationship of the children at school with their peers became better because the already get used to tell what they feel with appropriate ways stimulated by teachers in the topic of "Auratku/ My Private Parts". This result shows that sexuality education to children in Pearl Playschool since Playgroup could help children's psychosocial especially in Class B aged 5-7 years old.

The things need to be paid attention is the school has to conduct continuous training to their teachers 
in order to develop their competence in the materials related to: early childhood development, sexuality education to early childhood, and how to answer children's questions. This means that the training and enrichment given were not enough to improve the quality and competence of the teachers in sexuality education to early childhood.

One of the success factors of this program is that there is great parents' role and involvement. By involving parents in this program, the stimulation given by schools and teachers are the same. If parents have problems, the school provides special time to discuss with teachers and psychologists at school.

\section{ACKNOWLEDGEMENTS}

I would like to express my gratitude and thanks to Mrs.Vina Andriany, M.Ed. Ph. D, my advisor and mentor Mr. Bachruddin Musthafa, M.A, Ph.D., OkinaFitriani, Psi.M.Ed., Mr. Johandi Iskandar, Mrs. Siti Khodijah, and Mr. Ahmad Zaqi as my main supporters. Thank you for the motivation and the patience, which without their great support it would not be possible to conduct and finish my very first paper.

\section{REFERENCES}

Creswell, J.W. 2010. Research Design: Pendekatan Kualitatif, Kuantitaif, dan Mixed, Edisi Ketiga Yogyakarta: Pustaka Pelajar

Creswell, J.W. 2015. Penelitian Kualitatif \& Design Riset : Memilih diantara lima pendekatan., Edisi Ketiga. Yogyakarta: Pustaka Pelajar Chomaria, N. 2014. Pelecehan Anak, Kenali dan Tangani, Menjaga Buah Hati dari Sindrom. Solo : Tiga Serangkai

Dwiyani, V. 2004. Ketika Buyung Bertanya. Jakarta : Elex Media Komputindo

Ideo, W. 2014. Aku Anak yang Berani, Bisa Melindungi Diri Sendiri. Jakarta : PT Gramedia Pustaka Utama

Kemdikbud.go.id/dokumen/pdf/renstra/Bab-I.pdf Novilla, L.B., Barnes, M.D.,De La Cruz, N.G, William, P.N. And Rogers, J. 2006. Public Health Perspectives on the Family : An Ecological Approach to Promoting Health in the Family and Community: Family \& Community Health, 29 (1), 28-42.

Nurhasmah, W. 2015. Implementasi Pendidikan Seksual Untuk Anak Usia Dini : Studi Kasus di Taman Kanak-Kanak Salman Al Farisi Kota Bandung Tahun Pelajaran 2014-2015. S1 thesis, Universitas Pendidikan Indonesia.

Ollerenshaw, J.A., \& Creswell, J.W. 2002. Narrative research : A comparison of two restroying data analysis approaches Qualitative Inquiry, 8,329347.

Roqib, M. 2008. Pendidikan Seks Pada Anak Usia Dini. Purwokerto : Insania/vol.13/No. 2/MeiAgustus 2008/271-286.

Sugiasih, I. 2006. Need assessment mengenai pemberian pendidikan seksual untuk yang dilakukan ibu untuk anak usia 3-5 tahun. Fakultas Psikologi Universitas Islam Sultan Agung. Proyeksi, Vol.6 (1), 71-81.

Santrock, J. W. 2007. Perkembangan Anak. Edisi Kesebelas, jilid 1. Erlangga : Bandung

Tretsakis, M. 2003. Seks dan anak-anak. Bandung : Pioner Jaya

The National Child Traumatic Stress Network. 2009. Sexual Develovement and behavior in Children. USA.

Turnbull, T. 2012. Communicating about sexual matters within the family: Facilitators and barriers. School and Student Health Education, UK, vol. 30 no. 2, 2012

WHO, BzGA. 2010. Standard for Sexuality Education in Europe : A framework for policy makers, educational and health authorities and specialist. Federal Centre for Health Education. 